\title{
Konsep Pendidikan Islam Holistik Prof. Dr. Tuty Alawiyah dan Relevansinya di Era Milenium
}

\author{
Amaliyatul Ulya \\ Mahasiswa Pasca Sarjana UIN Sunan Kalijaga Yogyakarta, Amaliyatululya89@gmail.com \\ Dr. Muqowwim S.Ag. M.Ag, \\ Dosen Pasca Sarjana UIN Sunan Kalijaga Yogyakarta, muqowim@uin-suka.ac.id \\ Dr. Radjasa M.Si, \\ Dosen Pasca Sarjana UIN Sunan Kalijaga Yogyakarta, radjasa@uin-suka.ac.id
}

\begin{abstract}
Prof. Dr. Tuty Awawiyah is a female scholar as well as educational thinker who succeded establishing and managing Pesantren-based schools starting form kindergarten, the elementary school, junior high school, the senior high school until the college. The Purpose of this paper is to add insight and treasure about the concept of holistic Islamic education of Prof. Dr. Tuty Alawiyah and its relevance in the Millenium Era. Based on reseach and literature review that have been done, Islamic holistic education can be interpreted as education that is able to answer the problems of education faced in the word of education di the millennium era, for Islamic holistic education is education that shapes something in a whole way, therefore it becomes a very large unity that any other exithing combination. In can be concluded that, some holictic Islamic Education concept form Prof. Dr Tuty Alawiyah are very relevant so it needs to be discussed and they will appropriate as a quide in the millennium Era.
\end{abstract}

Keyword: Tuty Alawiyah, Education, Millennium Era.

\begin{abstract}
Abstrak
Prof. Dr. Tuty Alawiyah adalah seorang Ulama wanita serta pemikir pendidikan yang berhasil mendirikan dan mengelola sekolah berbasis Pesantren mulai dari TK, SD, SMP, SMA sampai dengan Perguruan Tinggi. Tujuan penulisan ini adalah untuk menambah wawasan dan khazanah mengenai konsep pendidikan Islam holistik Prof. Dr. Tuty Alawiyah serta relevansinya di era Milenium. Berdasarkan penelitian/telaah pustaka yang telah dilakukan, konsep Pendidikan islam holistik merupakan konsep pendidikan yang mampu menjawab masalahmasalah pendidikan yang dihadapi dalam dunia pendidikan di era milenium saat ini, dikarena pendidikan islam holistik adalah pendidikan yang membentuk sesuatu dengan cara yang utuh sehingga sesuatu itu menjadi kesatuan yang sangat besar daripada suatu gabungan-gabungan yang ada lainnya. Dapat disimpulkan bahwa, beberapa konsep Pendidiikan Islam holistic Prof. Dr. Tuty Alawiyah sangat relevan sehingga perlu dibahas dan pantas dijadikan pedoman dalam pendidikan di era Milenium.
\end{abstract}

Kata Kunci: Tuty Alawiyah, Pendidikan, Era Milenium

LITERASI, Volume XI, No. $22020 \mid 139$ 


\section{PENDAHULUAN}

Pendidikan mempunyai kontribusi berharga untuk mencetak sikap dan kepribadian seseorang siswa. Terwujudnya kepribadian baik serta sikap dari setiap siswa adalah tujuan utama sebuah pendidikan. Pendidikan juga salah satu sarana untuk meningkatkan kualitas suatu bangsa, oleh karena itu tolak ukur untuk melihat kemajuan suatu bangsa dapat dilihat dari seberapa besar kontribusi pendidikan di dalam negaranya. ${ }^{1}$ Dari konsep tujuan pendidikan kita bisa melihat pentingnya pendidikan bagi setiap manusia, tetapi ada hal lain yang dihadapi yaitu permasalahan permasalahan dalam pendidikan. Salah satu sumber masalah dalam pendidikan yaitu meningkatnya sistem pendidikan dualistis dari faham sekularisme yang mendominasi, sehingga membawa krisis dalam segala aspek kehidupan. ${ }^{2}$ Hal ini menyebabkan pemisahan antara ilmu umum dengan ilmu agama, sehingga memberikan pengaruh nyata dalam pembentukan karakter siswa.

Sumber masalah lain dalam pendidikan yaitu adanya ancaman budaya digital pada anak milenial. Ancaman digital saat ini salah satunya adalah banyaknya kasus bullying terhadap anak di media sosial. Beberapa Ahli Pendidikan menginformasikan bahwa permasalahan bullying ini bukanlah masalah sederhana dan bisa diselesaikan bilamana ada kerjasama antara pihak sekolah yaitu guru, anak dan orangtua. ${ }^{3}$ Kenakalan pada remaja juga merupakan sumber masalah dalam pendidikan. Hal tersebut menyebabkan perilaku

${ }^{1}$ Rudi Mahfudin. Konsep pendidikan Islam KH Abdullah bin Nuh dan Relevansinya Dengan Pendidikan Islam Modern (Jakarta: Jurnal Studi AlQur'an Universitas Negeri Jakarta; Vol. 13, No. 2, 2017) hlm. 143

${ }^{2}$ Imron Rossidy, Pendidikan Berparadigma Inklusif, Upaya Memadukan Pengokohan Akidah dengan Pengembangan Sikap Toleransi dan Kerukunan (Malang: UIN Malang Press, 2009) hlm. 61.

${ }^{3}$ Administrator. " Masih amakah kehidupan anak di era digital " https://www.pikiran-rakyat.com/pendidikan/ pr-01268139/masih-amankah-kehidupan-anak-di-eradigital-385533. diakses tanggal 21 Februari 2020 perilaku yang meyimpang pada remaja ${ }^{4}$ antara lain sering keluar malam dan menghabiskan waktunya hanya untuk hura-hura seperti minum-minuman keras, menggunakan obatobatan terlarang, berkelahi, berjudi. yang akan merugikan dirinya sendiri, keluarga, dan orang lain yang ada disekitarnya. ${ }^{5}$

Ciri lain dari sikap generasi milenial yang menonjol antara lain suka dengan kebebasan, selalu mengandalkan kecepatan informasi, generasi yang suka belajar, aktif, kreatif, inovatif, hyper technology, terbiasa berfikir out of the box, kaya ide dan gagasan, percaya diri yang tinggi, pandai besosialisasi serta pintar berselancar di dunia maya. Hal ini mengakibatkan beberapa generasi milenial menjadi pribadi yang malas, kurang bisa bersosialisasi dengan yang berlainan lingkungan serta cenderung lemah dalam nilai-nilai kebersamaan, kegotongroyongan, kehangatan lingkungan dan kepedulian social, cenderung bebas, kebarat-baratan dan tidak memperhatikan etik dan aturan formal, adat istiadat, serta tata krama. ${ }^{6}$

Faktor penyebab dari fenomena social yang terjadi di masyarakat yaitu adanya keterkaitan pendidikan dengan kemajuan teknologi yang begitu pesat, persaingan ekonomi yang cepat sehingga hanya SDM yang mampu beradapatasi dengan cepat dan berkompeten yang dibutuhkan. Namun, diantara fenomena tersebut muncul pula sikap sikap negatif yang muncul di era milenium saat ini antara lain sikap hedonisme, materialisme, individualisme, dan sebagainya. Disinilah pendidikan islam diharapkan mampu menangani masalahmasalah pada era milenium saat ini.

Dalam dunia pendidikan ada aspek yang satu sama lain saling berkaitan dan harus bekerja sama yaitu keluarga, sekolah

${ }^{4}$ Dahlia Novarianing Asri, Kenakalan Remaja : Suatu probematika social di era milenial. (Madiun: Prossiding SNBK 2 (1), 1 -8, 2018) hlm. 1

${ }^{5}$ Dadan Sumara, dkk, Kenakalan remaja dan penangannya.( Bandung, Jurnal Penelitian \& PPM Vol 4 No:2, 2017), hlm. 130

${ }^{6}$ Prof. Dr.Abuddin Nata. Pendidikan Islam di Era Milenial.( Conciencia: Jakarta, 2019), hlm. 1 
dan masyarakat. Pendidikan berupaya mendidik manusia untuk memiliki ilmu pengetahuan dan ketrampilan disertai dengan tetap beriman dan bertaqwa kepada Allah SWT, sehingga dia akan mengunakan ilmu pengetahuan dan ketrampilan dengan sebaik baiknya dan bermafaat. Manusia berpendidikan diharapkan unggul, sigap dan siap dalam menghadapi beberapa hambatan, dan perubahan yang muncul dalam pergaulan di masyarakat baik dalam lingkup lokal, nasional, regional maupun global.

Untuk mencetak manusia berpendidikan Unggul maka pendidikan agama harus dijadikan pedoman serta bagian dari bebagai aspek kehidupan. Selain itu, pendidikan dikotomi ilmu antara ilmu agama dan ilmu umum harus di gantikan dengan sistem pendidikan terpadu dan holistik. Pendidikan harus memberikan informasi kepada peserta didik tentang isuisu penting yang dihadapi oleh kemanusiaan, sekaligus harus mampu memberikan pemecahan atas masalah-masalah kemanusiaan tersebut. Dengan demikian, peserta didik memiliki kesadaran tentang hakikat dirinya, yaitu siapa, untuk apa, dan bagaimana. Pendidikan dengan gambaran seperti itu dinamakan dengan pendidikan holistik. ${ }^{7}$

Salah satu Tokoh Pemikir Pendidikan Islam Holistik dan Ulama perempuan yang dapat dijadikan teladan adalah Prof. Dr. Tuty Alawiyah. Beliau merupakah tokoh dan Ulama wanita yang bernama lengkap Dra. Hj. Tuty Alawiyah Abdullah Syafi'ie. Beliau lahir di Jakarta pada tanggal 30 Maret 1942 dan meninggal di Jakarta tanggal 4 Mei 2016 pada saat berusia 74 tahun. Beliau putri sulung dari sembilan bersaudara dari pasangan KH. Abdullah Syafi'ie yang merupakan Ulama Banten dan $\mathrm{Hj}$. Togayah. ${ }^{8}$ Beliau Menyelesaikan pendidikan SD sekaligus MI (1956), SMP dan MTS (1959) dan SMA

\footnotetext{
${ }^{7}$ Jejen Musfah. Dkk. Membumikan Pendidikan Holistik", Pendidikan Holistik; Pendekatan Lintas Perspektif. (Jakarta:Kencana, 2012) hlm. 3.

${ }^{8}$ Prof. Dr Hj Tutty Alawiyah. Penggagas dan penggerak keadilan Gender. (Jakarta: Pusat Studi Betawi UIA) Hlm. 15.
}

dan MAN (1962) semuanya di Jakarta, lalu melanjutkan ke IAIN Syarif Hidayatullah dan selesai 1976. Pendidikan Agamanya tidak hanya di sekolah tetapi beliau diajar langsung oleh ayahnya setiap malam sehingga beliau mampu menguasai ilmu agama sekaligus ilmu umum. Dengan penuh semangat dan tanpa rasa lelah beliau menekuni beberapa bidang sekaligus yaitu, bidang dakwah, sosial, sampai ke pendidikan yang merupakan fokus utamanya. ${ }^{9}$

Pada tahun 1977, Ia diberikan tugas oleh ayahnya yaitu Kyai Haji Abdullah Syafii untuk megelola pesantren khusus AsSyafi'iyah. Kontribusinya dalam pendidikan terwujud lewat keberhasilannya mengelola dan mengembangkan lembaga pendidikan mulai dari pesantren, madrasah, sekolah umum mulai dari tingkat Taman Kanak-Kanak sampai Perguruan Tinggi yang semuanya bernaung di bawah bendera Yayasan Perguruan As-Syafi'iyah. ${ }^{10}$ Perhatiannya dalam bidang pendidikan dapat dilihat dari sikapnya yang demokratis, terbuka, inovatif, kreatif serta mampu menjalin kerjasama dengan semua lembaga baik nasional mapun internasional.

Sekolah dan Pesantren yang dikelolanya berhasil mendidik anak anak khususnya anak anak yatim dan kurang mampu yang selalu semangat belajar pantang menyerah, memiliki pengetahuan agama yang kuat dan luas wawasannya dalam pengetahuan umum. Beliau berhasil mencetak ribuan anak didik yang berkiprah diberbagai sektor baik pemerintahan maupun swasta. Lulusan dari Pondok Pesantren dan sekolah As-Syafiiyahpun diberikan keleluasaan untuk bekerja dan focus di bidang yang diminati. Beberapa diantaranya menjadi Guru, Dosen, Ustadz, Perawat, Akuntan, Pembisnis dan beberapa menduduki jabatan baik di pemerintahan daerah maupun pemerintahan pusat.

Selain dilihat dari riwayat pendidikan, pengalamannya sebagai pendidik serta pemikirannya terhadap pendidikan ada alasan

\footnotetext{
${ }^{9}$ Ibid hlm 2

${ }^{10} \mathrm{Ibid}$, hlm 3
} 
lain yang membuat peneliti memilih ibu Tuty alawiyah sebagai sumber utama dalam penelitian ini. Alasan tersebut adalah karena banyaknya hasil karya tulis ibu Tuty Alawiyah mulai dari jurnal, buku yang ditulisnya sendiri. Salah satu buku hasil karya Ibu yang ditulis sendiri oleh beliau adalah bukunya yang berjudul "Peran Dakwah Millenium ke 3" yang diterbitkan pada tahun 2002 di Bekasi. Oleh karena itu, pemikiran Prof. Dr. Tuty Alawiyah tentang pendidikan sangat menarik untuk dikaji dan diteliti dengan mengacu pada teori pendidikan yaitu mencari tokoh pembaharu pendidikan yang ide ide serta pemikirannya dapat kita aplikasikan pada masa sekarang, sehingga idenya dapat membantu untuk menyelesaikan masalah masalah yang terjadi di dunia Pendidikan saat ini. Berdasarkan pendahuluan maka penelitian ini fokus pada konsep Pendidikan Islam Holistik Prof. Dr. Tuty Awaliyah serta relevansinya di era Milenium.

\section{METODE PENELITIAN}

Penelitian ini menggunakan pendekatan penelitian kualitatif. Penelitian kualitatif berangkat dari aliran positivistik yang menjelaskan bahwa pengalaman manusia merupakan sumber pengetahuan. ${ }^{11}$ Metode yang digunakan dalam penelitian ini adalah studi pustaka dengan teknik diskriptif analisis, artinya penelitian yang bersifat kepustakaan yang data-datanya di ambil dari bahanbahan tertulis, baik berupa buku atau lainnya yang berkaitan dengan topik pembahasan. Penelitian diskriptif merupakan penelitian yang dimaksudkan untuk mengumpulkan informasi mengenai status suatu gejala yang ada. ${ }^{12}$ Data yang digunakan adalah data kualitatif dengan menelaah pustaka dan referensi yang relevan. Cara yang digunakan adalah dengan mereduksi data, menyajikan data, dan menyimpulkan serta memeriksa hasil penelitian secara berkelanjutan dalam proses penelitian. Objek penelitian ini

\footnotetext{
${ }^{11}$ Prof. Dr. H. Wina Sanjaya, M.Pd. Penelitian Pendidikan. ( Jakarta: Prenada Media Grup, 2013) hlm. 34

${ }^{12}$ Arikunto. Manajemen Penelitian. (Jakarta: Rineka Cipta, 2010) hlm. 234
}

adalah pemikiran Prof. Tuty Alawiyah tentang pendidikan Islam holistik. Orientasi penelitian cenderung pada pemahaman konsep pendidikan Islam holistik dan relevansinya di era milenial. Agar pemahaman dalam permasalahan ini lebih komprehensif maka di awal pembahasan diuraikan tentang Prof. Dr. Tuty Alawiyah, kemudian pengertian pendidikan Islam holistik, konsep pendidikan holistic Prof Dr. Tuty Alawiyah, pengertian Era milenial dan ditutup dengan relevansi Pemikiran Prof Dr. Tuty Alawiyah Tentang Pendidikan Islam holistik di era milenial.

\section{HASIL DAN PEMBAHASAN \\ Gagasan Prof. Dr. Tuty Alawiyah}

Menurut beliau "Pendidikan merupakan suatu usaha (tindakan, action) yang dilakukan secara sadar) oleh suatu masyarakat atau kelompok yang bertujuan meningkatkan kehidupan manusia menjadi lebih bermutu, baik untuk kehidupan di dunia maupun untuk kehidupan di akhirat". ${ }^{13}$ Pendidikan menurutnya sesuai dengan konsep pendidikan holistik yaitu metode pendidikan yang membangun manusia secara menyeluruh dengan cara memaksimalkan semua potensi yang ada dalam diri manusia yang mencangkup potensi sosial, emosi, intelektual, moral atau karakter, kreatifitas, dan spiritual. ${ }^{14}$

Dalam bidang pendidikan beliaw meneruskan pemikiran ayahnya yaitu K.H. Abdullah Syafi'I yang memandang bahwa semua ilmu dapat dipelajari, baik ilmu agama maupun ilmu umum seperti ilmu kedokteran dll. Pendidikan Islam tidak boleh hanya mengajarkan satu bidang ilmu agama saja, melainkan juga mengajarkan bidang ilmu umum temasuk bidang seni dan keterampilan. Walaupun demikian materi pelajaran yang amat ditekankannya adalah materi pelajaran agama Islam. Berbagai bidang ilmu agama yang diajarkannya disekolahnya melalui kitab

\footnotetext{
${ }^{13}$ Tuty Alawiyah AS, Prof, Dr, MA, (Jakarta: Rapim UIA November 2010)

${ }^{14}$ Ratna Megawangi, Pendidikan Holistik (Cimanggis: Indonesia Heritage Foundation, 2005) hlm.5-6
} 
kuning, seperti Tafsir Jalalain, Riyadh alSholihin, al-Nashaih al-Diniyah.

\section{Tujuan pendidikan}

Tujuan pendidikan menurut Beliau ada beberapa aspek. Pertama, tugas utama manusia hidup di dunia adalah untuk mengabdi kepada Allah SAW (Q.S: 51/56). Kedua, manusia diciptakan oleh Allah di dunia untuk menjadi khalifah di muka bumi yang artinya menjadi pemimpin (Q.S:2/30). Ketiga, mampu beradaptasi dengan perkembangan masyarakat saat ini dan tetap melestarikan nilai budaya islami yang ada. Keempat, mampu menjadi manusia Muslim yang ideal sehingga dapat berkontribusi dalam bermanfaat dalam meningkatkan kesejahteraan hidup manusia lainnya serta dapat meraih kehidupan yang baik dunia dan akhirat ${ }^{15}$.

Pemikiran tersebut sesuai dengan tujuan pendidikan holistikyang berusaha memaksimalkan potensi potensi dan aspek menyeluruh pada diri siswa dan bermuara pada rasa kesadaran tentang keberadaan Tuhan. Peserta didik diarahkan untuk memahami masalah dalam lingkungannya dan berusaha ikut terlibat langsung dalam upaya pemecahan masalah-masalah lokal dan global. Pendidikan holistikjuga bertujuan memaksimalkan potensi peserta didik dalam lingkungan pembelajar yang sangat menyenangkan, demokratis dan humanis. Dengan adanya sistem pendidikan ini, peserta didik memperoleh kebebasan dalam mengambil suatu keputusan yang baik untuk dirinya serta dapat mengembangkan kecapakan social, karakter dan kepribadiannya. Dengan paradigma pendidikan yang demikian peserta didik dapat mengoptimalkan seluruh potensi yang mereka miliki, tanpa mengesampingkan aspek spiritual.

Berdasarkan rumusan tujuan yang disampaikan di awal, Prof Dr. Tuty Alawiyah berhasil mengelola pesantren dan lembaga pendidikannya menjadi lembaga pendidikan islam yang dapat mencetak anak didik yang menguasai ilmu agama dan juga sekaligus menguasai ilmu

${ }^{15}$ Prof.Dr.Dailami Firdaus, SH.,LL.M.,MBA. 70 Tahun Tuty Alawiyah. (Jakarta: UIA Press, 2012), hlm: 49 pengetahuan umum. Terbukti dengan didirikannya TK islam, SD islam, SPM islam, SMA islam, Madrasah Diniah serta Universitas UIA yang memadukan antara bentuk tradisi pendidikan Islam yang konvensional dan pendidikan formal dengan standard sekolah dan kampus dari pemerintah. Semua murid yang bersekolah wajib belajar ilmu agama dan ilmu umum, supaya dapat menjawab tantangan Global. Dari sekolah dan Kampus yang didirikannya berhasil mencetak ribuan bahkan jutaan murid yang berperan di berbagai bidang.

\section{Kurikulum pendidikan}

Kurikulum meliputi semua hal yang bisa mempengaruhi pembelajaran kepada peserta didik baik itu langsung maupun tak langsung antara lain buku pelajaran, interaksi guru-murid, murid dengan murid, murid dengan karyawan, perpustakaan, kantin, taman, program, tata tertib, suasana dan kondisi kelas dan sekolah. Karena itu, semua hal tersebut harus dirancang dengan matang untuk pembelajaran. ${ }^{16}$

Beberapa ciri dari generasi milenial anta lain pandangannya yang luas terhadap sesuatu, tidak ingin dikekang oleh suatu pendapat. Generasi milenial akan terus mencari informasi baru, membuka diri, berintegrasi dengan banyak pemikiran, pandangan serta gagasan sehingga memperoleh jawaban yang kompleks. Selain itu, masalah moral, seperti korupsi, perkosaan, dan penipuan, masalah spiritual seperti tidak tidak merasa berdosa kalau berbuat maksiat dan kesalahan, selalu merasa tidak puas, masalah sosial seperti konflik yang dipicu isu SARA, bahkan penjajahan dan peperangan, tidak dapat diatasi oleh ilmu dan teknologi canggih semata. Pemecahan masalah tersebut membutuhkan agama, moral dan spiritual ${ }^{17}$ Dalam menghadapi watak dari generasi milenial, maka pendidikan islam harus dapat mengkolaborasikan antara ilmu agama dan ilmu umum.

Kurikulum pendidikan yang dirumuskan Prof. Tuty Alawiyah yaitu dalam lembaga

\footnotetext{
${ }^{16}$ Jejen Musfah. Dkk. Membumikan .., hlm. 13.

${ }^{17}$ Prof. Dr. Abuddin Nata. Pendidikan ... hlm: 2
} 
pendidikan hendaklah ilmu - ilmu agama (ulum ad-din) dan ilmu-ilmu umum (ulum-al-ammah) berjalan secara seimbang dan serasi. Dalam Islam tidak ada istilah dikotomi atau pemisahan pendidikan karena pada dasarnya semua ilmu baik itu ilmu agama dan ilmu umum bersumber pada a)Al- qur'an; b) sunah; c) alam semesta; d) manusia; e) sejarah umat manusia. Menurutnya hukum mempelajari ilmu-ilmu agama/ ilmu akhirat adalah fardlu' ain yaitu wajib sedangkan mempelajari ilmu ilmu dunia yang juga secara tidak langsung bersumberkan kepada Al-Qur'an adalah Sunnah atau fardlu kifayah. ${ }^{18}$

Dalam kurikulum di sekolah yang dikelolanya peserta didik diberikan kesempatan untuk mengembangkan bakat sesuai minatnya. Dalam banyak hal beliau selalu memberikan keleluasaan anak didik untuk mendalami dunia yang diminati anak, misalnya di seni maka diadakan kegiatan extra antara lain paduan suara, marawis, hadrah, melukis, kaligrafi dll. Di Dunia olahraga beliau mengadakan kegiatan extra di sekolahnya atara lain olahraga basket, olahraga bulu tangkis, olahraga sepak bola, olahraga Kasti dll

Menyadari tantangan pendidikan yang dihadapi, output pendidikan Islam perlu mempertimbangakan aspek aspek relevansi, mutu dan masalah fungsional. Agar output pendidikan dapat memenuhi standar yang diperlukan suatu generasi islam yang kreatif dan produktif. Berikut Prinsip prinsip dalam Kurikulum pendidikan islam holistik yang dirumuskan Prof. Tuty Alawiyah.

Prinsip yang pertama yaitu pendidikan islam harus mampu mendidik siswa untuk menjadi stive for exellence. Dalam hal ini siswa harus ditanamkan untuk selalu bersikap menghargai dan berusaha secara maksimal menjadi yang terbaik di setiap mata pelajaran. ${ }^{19}$ Hal ini dilakukan dengan cara memberikan motivasi serta mendorong siswa agar belajar

\footnotetext{
${ }^{18}$ Prof.Dr.Dailami Firdaus, SH.,LL.M.,MBA. 70 Tahun ..., hlm 50-51

${ }^{19}$ DR. H. Tuty Alawiyah AS. Perempuan dan Masyarakat Pembelajaran. ( Legasi Indonesia. Jakarta; 2002) hlm; 5
}

sendiri, mampu menganalisa pertanyaan yang diberikan dan dapat menjawab pertanyaan dengan tepat. Prinsip Kedua, Pendidikan islam harus didasarkan pada prinsip keadilan sosial. Dalam hal ini siswa harus didorong untuk menghargai pengetahuan dan ketrampilan yang sudah lama dan memiliki nilai nilai dalam masyarakat islam khususnya masyarakat Indonesia. Dalam hal ini Pendidikan siswa harus mampu melihat secara adil bakat dan kemapuan siswa, yaitu dengan cara memberikan kesempatan secara adil kepada siswa untuk mencapai keberhasilan dalam pendidikannya. ${ }^{20}$

Prinsip Ketiga, pendidikan islam harus mampu melahirkan siswa yang senang bekerjasama (foster cooperation) dan memiliki moral serta etika ke-islaman yang sangat kuat, seperti kejujuran, penghargaan pada diri sendiri dan teman serta penghargaan pada waktu, kerjasama dan sikap adil. Keempat, Pendidikan islam harus mampu melahirkan generasi yang percaya pada diri sendiri dengan cara siswa harus mengenali kelebihan dan kekurangan diri sendiri secara ikhlas dengan cara itu siswa didorong untuk memanfaatkan kelebihankelebihannya secara produktif. Prinsip Kelima, pendidikan Islam harus berkembang dan mampu beradaptasi dengan dengan lingkungan. ${ }^{21}$

Dalam hal ini penulis menegaskan bahwa Pendidikan Islam Holistic Prof. Tuty Alwiyah merupakan adalah suatu sistem pendidikan yang utuh atau menyeluruh yaitu adanya keterkaitan yang tidak bisa dipisahkan antara ilmu agama dan ilmu umum. Pendidikan di era millinium harus mengajarkan ilmu agama secara utuh dan juga memberikan berbagai ilmu umum termasuk seni dan olahraga. Pendidikan pada masa ini, mengarahkan para peserta didik untuk bisa menjadi pribadi yang memiliki nilai kesadaran yang tinggi dalam suatu kemasyarakatan dan di dalam dirinya sendiri serta memberikan pemahaman kepada para peserta didik tentang persoalan - persoalan yang terjadi disekitarnya. Dengan demikian peserta didik diharapkan

\footnotetext{
${ }^{20}$ DR. H. Tuty Alawiyah AS. Perempuan .. hlm; 5-6 ${ }^{21}$ DR. H. Tuty Alawiyah AS. Perempuan .. hlm; 5-6
} 
mampu untuk bisa menyelesaikan persoalanpersoalan masalah tersebut sesuai dengan aturan-aturan pendidikan Islam yang telah dianjurkan atau sesuai dengan koridor yang telah ada dalam al-Qur'an dan Hadist.

\section{Pengajar/ Guru}

Salah satu komponen penting dalam pendidikan adalah Guru/ Pengajar/ Dosen juga harus memiliki kriteria kriteri tertentu. Menurut Prof. Tuty Alawiyah kriteria yang harus dimilki oleh seorang Guru/ Pengajar yaitu;

Pertama, Seorang Guru/ Dosen harus memiliki ilmu dan wawasan yang luas dengan mengikuti jenjang pendidikan yang lebih tinggi dan linier.

Kedua, Seorang Pengajar harus banyak belajar dan tidak boleh merasa puas dengan ilmu yang dimilikinya.

Ketiga, Seorang Pengajar hendaklah selalu kreatif, inovatif dalam proses belajarmengajar, seperti membuat diktat, buku panduan yang dijadikan pegangan oleh peserta didik.

Keempat, Seorang pengajar hendaklah meningkatkan budaya akademik melalui pendidikan, penelitian dan pengembangan kemasyarakatan.

Kelima, Seorang Pengajar hendaklah memelihara citra, kompetitif dan egoistic.

Keenam, Seorang Pengajar hendaklah membentuk situasi belajar dan mengajar yang kondusif dan membantu menyiapkan fasilitas belajar yang mendukung agar terwujudnya proses belajar-mengajar yang menyenangkan. ${ }^{22}$

Pernyataan diatas menunjukkan bahwa Pendidik merupakan orang yang penting dalam proses pengembangan potensi dalam diri siswa. Pendidik juga yang membuat seorang siswa menjadi manusia yang memiliki sifat kemanusiannya sehingga seorang pendidik harus mau belajar dan menjadi model terbaik bagi siswa didiknya. ${ }^{23}$ Melalui keteladanan yang dilakukan oleh seorang Guru, maka siswa dapat

${ }^{22}$ Prof.Dr.Dailami Firdaus, SH.,LL.M.,MBA. 70 Tahun ..., hlm: 51-52

${ }^{23}$ Dr. Helmawati, S.E., M.Pdi. Pendidik sebagai Model. (2017, Bandung: PT Remaja Rosdakarya) hlm: 1 dibimbing untuk mengendalikan keinginan diri sendiri dan menghargai perbedaan sehingga terciptalah toleransi. Buah dari toleransi adalah mengikatkuatkan tali ikatan persaudaraan sesama manusia di muka bumi ini yang memiliki perbedaan-perbedaan. Toleransi melahirkan pribadi yang bersikap secara elegan dan bijaksana dalam menyikapi

\section{Peserta didik}

Peserta didik merupakan komponen penting dalam pendidikan. Peserta didik diharuskan selalu meningkatkan kualitas dan kuantitas agar mampu berkompetisi dan menjadi sumber daya manusia (SDM) unggul. Menurut Prof. Tuty Alawiyah peserta didik yang yang ingin dibentuk dalam pendidikan adalah:

"cerdas dan memiliki spiritual (rohani) yang sehat, Memilki kemampuan intelektual, perasaan dan kehalusan budi, menghargai orang tua, Guru, Dosen dan berbusana muslimah, terbuka cinta lingkungan, cinta agama dan Al-Qur'an, Bersyukur dan berpikir mau ke depan". ${ }^{24}$

Hal tersebut terlihat dalam slogan yang beliaw buat dan selalu disampaikan kepada anak didiknya yaitu unggul dalam " IMTAQ \& IPTEK”. IMTAQ berarti Iman dan Taqwa sedangkan IPTEQ berarti ilmu pengertahuan dan teknologi. Jadi setiap pererta didik wajib unggul dalam bidang agama dan ilmu umum sehingga kedepannya dapat peserta menjadi pribadi didik agamis dan unggul serta dapat mengelola kekayaan sumber daya alam yang ada di Indonesia. ${ }^{25}$

\section{Metode pengajaran}

Konsep metode pendidikan holistik menjadikan pendidikan spiritual yaitu agama sebagai dasar utama dalam pengembangan ilmu umum. Metode pengajaran yang paling efektif

\footnotetext{
${ }^{24}$ Ibid., hal. 54

${ }^{25}$ Nasih Nasrullah, Milad ke-80 As-Syafi'iyah Momentum meneguhkan kiprah (https://www.republika. co.id/berita/dunia-islam/khazanah/13/11/23/mwpluhmilad-ke80-assyafiiyah-momentum-meneguhkan-kiprah. Diakses tanggal 22 Februari 2020)
} 
pertama yang digunakan adalah menggunakan komunikasi dua arah, yaitu diskusi atau dialog. Metode ini mampu mengembangkan daya berpikir peserta didik yang kritis dan mampu mengelola informasi yang masuk menjadi informasi-informasi baru. Metode yang kedua adalah menggunakan buku atau sumber-sumber ilmu sebagai central. ${ }^{26}$ Dalam metode kedua Guru bukanlah satu satunya sumber dalam pembelajaran karena kemampuan guru terbatas sehingga peserta didik dibiasakan untuk menggunakan sumber buku sebagai sumber ilmu. Dengan pendekatan ini, peserta didik mampu melihat menganalisa perbedaan pemikiran dari satu tokoh dengan tokoh yang lain dan mencari solusinya sendiri. ${ }^{27}$

Beberapa Metode yang digunakan oleh Prof. Tuty Alawiyah dalam pembelajaran di sekolahnya antara lain metode talqin dan metode diskusi. Metode talqin dilakukan dengan mendengarkan bacaan oleh salah seorang murid yang baik bacaanya, kemudian diikuti murid murid lain. Karena kemampuan peserta didik berbeda beda maka peserta didik yang memiliki kemampuan lebih dapat membantu peserta didik yang kemampuannya terbatas. Metode ini melatih siswa untuk selalu tolong menolong dan mau membantu orang lain. Metode diskusi juga digunakan dalam aktivitas pendidikan terutama anak anak didik di tingkat akhir. Metode ini membiasakan peserta didik untuk mengungkapkan pendapatnya sehingga proses belajar mengajar menjadi menyenangkan. Metode lainnya yaitu menggunakan pengulangan (repetition, takrak) atas materi pelajaran yang telah diberikan sebelumnya agar anak didik memahami dan mengerti sub-sub materi yang telah diberikan dengan materi yang sedang diberikan. ${ }^{28}$

\section{Strategi Pendidikan}

Pemikiran dan gerakan Prof. Tutty bersifat kultural dan multikultural yang berarti

\footnotetext{
${ }^{26}$ Nanik Rubiyanto dan Dany Haryanto, Strategi Pembelajaran Holistik Di Sekolah (Jakarta : prestasi pustakarya,2010) hlm.33

27

${ }^{28}$ Prof. Dr. Dailami Firdaus, SH., LL.M.,MBA. 70 tahun ..., hlm: 55
}

mampu memahami dan menghargai perbedaan pandangan baik internal maupun eksternal. ${ }^{29}$ Beliaw melihat Pribadi manusia dengan tidak melihat latar belakangnya,tapi melihat semangatnya untuk belajar. Hal itu terlihat dari lembaga pendidikanya yang menerima peserta didik tanpa melihat etnis dan sukunya, bahkan beliaw memberikan kesempatan yang sama kepada peserta didik non muslim mengikuti pendidikan di sekolahnya.

Beberapa hal yang harus dipertimbangkan dalam mengembangkan strategi pembelajaran islam holistic antara lain , 1) menggunakan pendekatan transformatif; 2) prosedur pembelajaran yang fleksibel; 3) pemecahan melalui ${ }^{30}$ lintas disiplin ilmu; 4) pembelajaran yang bermakna; 5) pembelajaran melibatkan komunitas dimana individu berada. ${ }^{31}$

\section{Manajemen pendidikan}

Dalam hal manajemen pendidikan, Prof Tuty Alawiyah menyadari benar bahwa untuk memajukan pendidikan perlu adanya manajemen pendidikan yang kuat dan professional. Sehingga dalam hal mewujudkan manajemen yang handal beliau mendirikan Yayasan As-syafiiyah lengkap dengan organisasinya. Yayasan As-Syafiiyah di dirikan untuk mengemban pendidikan di wilayah bekasi dan sekitarnya, dan sangat diupayakan keseluruh belahan dunia, karena itulah sedapat mungkin gerakan dakwah ini memanfaatkan sarana ilmu pengetahuan dan teknologi, serta membantu program pemerintah Indonesia dalam membina mental bangsa, memajukan pendidikan, menjunjung tinggi syiar agama Islam, dan menggalang ukhuwah Islamiyah. Yayasan As-Syafiiyah membuka sekolah mulai dari TK, SD, SMP, SMA dan SMK Umum berkonsep Pesantren.

\footnotetext{
${ }^{29}$ Ilyas Ismail. Dekan Fakultas Agama Islam Universitas Islam As-Syafi iyah Jakarta (http:// arsip.gatra.com/2016-07-03/majalah/artikel. php?pil=23\&id=161999. Diakses tanggal 22 Februari 2020)

${ }^{30}$ Jejen Musfah, Membumikan.....

${ }^{31}$ Nanik Rubiyanto dan Dany Haryanto, Strategi ..., hlm:33
} 


\section{Evaluasi}

Banyak Pakar Pendidikan yang mengungkapkan bahwa Evaluasi sangat penting dalam pengembangan Pendidikan. Tujuan evalusi adalah memantau dan mengevalusi jalannya proses belajar dan mengajar dan mengetahui daya serap peserta didik terhadap materi yang diberikan. Tolak ukur keberhasilan seorang siswa dalam mengenyam pendidikan dapat diukur melalui perubahan sikap dan perilaku yaitu di nilai dari proses, pengalaman, dan kondisi perubahan yang dialami selama berada pada proses belajar dibangku sekolah. Seorang pendidik memiliki peran besar dalam mendampingi siswa untuk memiliki pengalaman dan pemahaman tentang nilai-nilai hidup berkarakter. ${ }^{32}$

Kunci kesuksesan lembaga Pendidikan yang dikelola Prof. Tuty Alawiyah adalah rajin dan selalu melakukan evaluasi dari semua sudut pendidikan. Sikapnya yang demokratis yaitu terbuka, selalu bermusyawarah, berdiskusi, menerima masukan dari dengan seluruh pengurus dan anggota yayasan As-Syafiiyah membuat lembaga pendidikan ini dapat berkembang secara pesat. Beliau juga membuka kerjasama dengan berbagai pihak baik pemerintah, lembaga nasional maupun internasional untuk kemajuan lembaga pendidikanya.

\section{Relevansinya di era Milenial}

Berdasarkan hasil pemaparan diatas, konsep Pendidikan Islam hoslistik Prof. Dr. Tuty Alawiyah sangat relevan diterapkan di era milenial. Hal tersebut terlihat dan terbukti dari konsep pendidikan beliau meliputi tujuan pendidikan Islam, kurikulum (rencana pengajaran), metode (cara mengajar), guru (pendidik), peserta didik, lingkungan pendidikan, memberi nilai (evaluasi) semuanya sesuai dan dapat diterapkan dalam dunia pendidikan di era Milenial.

${ }^{32}$ Zakiyah Kholilah. Relevansi pemikiran Muhammad Iqbal dalam pembentukan Karakter Siswa di Era Millenium. (Jurnal Studi Pendidikan Islam Vol.1 No.2 Juli 2018). hlm. 70
Tugas Pendidikan di era milenial, yaitu menanamkan dasar tauhid yang kuat, akhlak mulia, mengawal umat manusia dalam proses perubahan hidupnya dari satu tahap ke tahap lainnya secara seimbang. Dalam mendidik murid di era milenial maka seorang pendidik harus menyampaikan kepada peserta didik tentang ciri-ciri dan tantangan-tantangan, wawasan, ilmu, keterampilan atau keahlian yang harus mereka miliki agar mereka dapat merubah tantangan-tantangan yang dihadapinya menjadi peluang serta mampu menggunakannya dengan tepat.

Sikap yang dinamis, inovatif, kreatif, dan berani keluar dari kebiasaan lama (out of the box) yang muncul di era millennium misalnya dapat diterima oleh ajaran Islam. Tujuan pendidikan holistik Islami berarti mengembangkan seluruh bakat yang dimiliki peserta didik kearah perkembangannya yang sempurna serta menolong manusia agar eksis dalam melaksanakan fungsinya yaitu sebagai Khalifah dimuka bumi sebagai masyarakat yang menjaga alam semesta, sehingga kapasitas keimanan, ilmu, dan amal setiap manusia selalu mengalami peningkatan yang lebih baik dari sebelumnya ${ }^{33}$ Hal tersebut sesuai dengan apa yang yang disampaikan Prof. Tuty Alawiyah tentang tujuan pendidikan yaitu menuntun peserta didik agar dapat melestarikan nilai budaya islami serta dapat memenuhi kebutuhan hidupnya dalam perkembangan dunia modern serta menjadi manusia Muslim yang ideal yang mampu meningkatkan kesejahteraan hidunya untuk berusaha lebih maksimal guna meraih kehidupan yang terbaik dunia dan akhirat.

Kurikulum pendidikan Prof. Dr. Tuty Alawiyah juga memberikan masukan agar setiap madrasah khusunya dapat mewadahi dan memfasilitasi berbagai minat bakat anak didik sehingga anak didik berkembang sesuai minat bakatnya serta tidak memaksakan minat anak. Bakat dan minat anak yang terasah baik akan menjadikan anak lebih kreatif dan aktif dan itu sesuai dengan kebutuhan di era millium saat

\footnotetext{
${ }^{33}$ Jejen Musfah, Membumikan..., hlm. 271
} 
ini. Siswa memiliki kecakapan/potensi yang tersembunyi dalam dirinya dapat di asah dan dikembangkan melalui proses belajar. Potensi yang ada pada diri siswa mencakup kecerdasan, bakat, dan kreatifitas. Ketiganya apabila diasah dan dilatih secara berulang-ulang sampai menjadi sebuah kebiasaan bagi siswa maka akan nampak jelas kecermelangan potensi yang dimiliki siswa menjadi sebuah prestasi unggul yang di raih siswa dalam hidupnya. ${ }^{34}$

Di era milenial banyak berkembang metode mengajar saat ini terutama metode mengajar yang berkembang dari barat yang di dukung dengan semakin berkembangnya IPTEK. Beberapa metode pembelajaran yang dikemukakan oleh Prof. Tuty Alawiyah ada beberapa yang dipakai hingga saat ini diantaranya metode diskusi atau istilahnya Student Aktif Learning yang banyak digunakan dalam pembelajaran kelas akhir/ kelas atas. Dalam hal ini peserta didik dituntuk untuk aktif bertanya dan berdiskusi sehingga kemampuan berbicara serta mengungkapkan pendapatnya terasah dengan baik. Cara berdiskusipun dalam pendidikan islam ada aturan atau etika berdiskusi yaitu memonopoli pembicaraan, menghargai pendapat orang lain, luas dalam berpikir.

Pendidik merupakan komponen utama yang sangat penting dalam sistem pendidikan, karena Pendidik dapat mengantarkan peserta didik untuk mencapai tujuan yang telah ditentukan. Pendidik/ Guru di Era Milenium saat ini dituntut untuk mempunyai wawasan luas, kreatif, inovatif mampu menggunakan teknologi dengan baik sehingga mampu mengarahkan dan mendampingi generasi milenial agar dapat menggunakan digital dengan baik dan benar.

Setiap sekolah dan madrasah hendaknya memberikan kesempatan yang sama untuk kaum Yatim Duafa untuk mengenyam pendidikan sekolah dengan memberikan bantuan pendidikan atau memberikan sekolah gratis untuk kaum Yatim Duafa, sehingga mereka akan menjadi generasi penerus yang berpendidikan baik dan

${ }^{34}$ Zakiyah Kholilah. Relevansi....hlm: 85 ikut memajukan bangsa. Tidak hanya anak didik yang perlu diedukasi tapi orang tua juga perlu untuk belajar sehingga paham dan mampu memberikan pendidikan terbaik untuk anak anak. Orang Tua juga perlu belajar menjadi orang tua teladan yang mengerti perkembangan anak sehingga anak anak menjadi generasi penerus bangsa yang sukses dunia dan akhirat. Oleh karenanya, untuk orang tua dapat belajar melalui majlis ta'lim dan sekolah sekolah khusus untuk orang tua.

\section{KESIMPULAN}

Berdasarkan hasil analisis dapat diambil kesimpulan bahwa konsep pendidikan Prof. Dr. Tuty Alawiyah sangat relevan diterapkan di era milenial baik dilihat dari tujuan Pendikan, metode pendikan, kurikulum pendidikan, kriteria pendidik serta peserta didik, metode pendidikan, strategi pendidikan serta evaluasi pendidikan.

Pertama, tujuan pendidikannya sesuai dengan K-13 yaitu pendidikan yang mengembangkan segala potensi peserta didik atau elemen yang ada yaitu elemen intelektual, fisik, emosi, dan spiritual. Hingga mampu menghasilkan output yang unggul dalam diri peserta didik. Kedua melalui metode pendidikan yang disampaikan diharapkan dapat menempatkan siswa dalam posisi sentral atau student aktif learning yang menempatkan siswa sebagai peserta didik yang aktif, terutama dalam keterampilan berfikir. Ketiga, kurikulum yang disampaikan adalah kurikulum intergratif yang memadukan antara agama dan ilmu umum sehingga murid mampu mengusai kedua ilmu tersebut secara seimbang. Keempat, komponen guru yang harus dimiliki di era milenium guru yang berwawasan luas, kreatif dan inovatif serta dapat memberikan teladan bagi muridnya. Kelima, evalusi pendidikan harus selalu dilakukan di semua sudut pendidikan. Lembaga pendidikan akan berkembang pesat manakala selalu melakukan inovasi, terbuka mampu beradaptasi dengan zaman serta mau menjalin kerjasama dengan pihak nasional maupun internasional. 


\section{DAFTAR PUSTAKA}

Alawiyah, T,. (Jakarta: Rapim UIA November 2010)

Alawiyah, T,. Perempuan dan Masyarakat Pembelajaran ( Legasi Indonesia. Jakarta; 2002)

Alawiyah, T. Penggagas dan penggerak keadilan Gender. (Pusat Studi Betawi UIA. Jakarta:2002).

Administrator "Masih amakah kehidupan anak di era digital" (https://www.pikiranrakyat.com/pendidikan/pr-01268139/ masih-amankah-kehidupan-anak-diera-digital 385533. diakses tanggal 21 Februari 2020)

Arikunto. Manajemen Penelitian.(Rineka Cipta, Jakarta: 2010)

Asri, Dahlia Novarianing. Kenakalan Remaja : Suatu probematika social di era milenial. (Prossiding SNBK 2 (1), 1 -8: Madiun, 2018)

Dadan Sumara, dkk, Kenakalan remaja dan penangannya. ( Jurnal Penelitian \& PPM Vol 4 No:2: Bandung, 2017)

Firdaus, D,. 70 Tahun Tuty Alawiyah. (UIA Press: Jakarta, 2012)

Helmawati,. Pendidik sebagai Model. (Bandung: PT Remaja Rosdakarya, 2017)

Ismail, I. Dekan Fakultas Agama Islam Universitas Islam As-Syafi iyah Jakarta, http://arsip.gatra.com/2016-07-03/ majalah/artikel.php?pil=23\&id=161999. Diakses tanggal 22 Februari 2020
Kholilah, Z,. Relevansi pemikiran Muhammad Iqbal dalam pembentukan Karakter Siswa di Era Millenium. (Jurnal Studi Pendidikan Islam Vol.1 No.2 Juli 2018).

Rossidy, I,. Pendidikan Berparadigma Inklusif, Upaya Memadukan Pengokohan Akidah dengan Pengembangan Sikap Toleransi dan Kerukunan, (Malang: UIN Malang Press, 2009)

Rubiyanto, N,. dan Dany Haryanto, Strategi Pembelajaran Holistik Di Sekolah, (Jakarta : prestasi pustakarya, 2010)

Sanjaya, W. Penelitian Pendidikan. ( Jakarta: Prenada Media Grup, 2013)

Mahfudin, R,. Konsep pendidikan Islam KH Abdullah bin Nuh dan Relevansinya Dengan Pendidikan Islam Modern. (Jakarta: Jurnal Studi Al-Qur'an Universitas Negeri Jakarta; Vol. 13, No. 2 , Tahun. 2017)

Megawangi, R,. Pendidikan Holistik (Cimanggis: Indonesia Heritage Foundation, 2005)

Musfah, J,. Dkk. Membumikan Pendidikan Holistik", Pendidikan Holistik; Pendekatan Lintas Perspektif. (Jakarta:Kencana, 2012)

Nata.A., Pendidikan Islam di Era Milenial, (Conciencia: Jakarta, 2019)

Nasrullah Nashih, Milad ke 80 As-Syafi'iyah Momentum meneguhkan kiprah (https:// www.republika.co.id/berita/dunia-islam/ khazanah/13/11/23/mwp1 uh-milad-ke80assyafiiyah-momentum-meneguhkankiprah. Diakses tanggal 22 Februari 2020) 